\title{
LIFE AND ACADEMIC ACTIVITIES OF PROFESSORS EMERITI AND RETIRED PROFESSORS ON UNIVERSITY OF MARIBOR
}

\section{ŽIVOTNE I AKADEMSKE AKTIVNOSTI ZASLUŽNIH I UMIROVLJENIH PROFESORA SVEUČILIŠTA U MARIBORU}

\author{
Dušanka Mičetić-Turk 1,2, Maja Šikić Pogačar 2, Zmago Turk ${ }^{1}$ \\ Center for Retired and Meritorious Professors of the University of Maribor, Maribor, Slovenia ${ }^{1}$; Faculty of Medicine, Uni- \\ versity of Maribor, Maribor, Slovenia ${ }^{2}$ \\ Centar za umirovljene i zaslužne profesore Sveučilišta u Mariboru, Maribor, Slovenija ${ }^{1}$; Medicinski fakultet, Sveučilište u \\ Mariboru, Maribor, Slovenija, ${ }^{2}$
}

\section{Abstract}

Higher education lecturers go through a long developmental path from graduate students to academic title of professor. On this path, the most delicate period is the retirement. The age of 60 or 65 , which is approximately the same as the retirement age in most developed countries, is supposed to be the onset of old age. Today, when we live longer and healthier, irreparable damage would occur if society and the state didn't take advantage of the knowledge, wisdom and skills that senior professors have accumulated throughout their careers. The vast majority of senior professors could still contribute and participate in the development of society. In our article, we presented the results of a survey regarding the academic and life activities of senior professors, members of the Center for Retired and Distinguished higher education teachers of the University of Maribor. The results showed that the vast majority of retired and professors emeriti were still active in academic life and contributed to the development and functioning of the University.

\section{Sažetak}

Visokoškolski učitelji prolaze dugi razvojni put od diplomanta do profesora. Na tom putu je jedno od najdelikatnijih razdoblja odlazak u mirovinu. Starost od 60 ili 65 godina, otprilike ista kao i starost za umirovljenje $\mathrm{u}$ većini razvijenih zemalja, označava početak starosti. Danas, kada živimo duže i zdravije, događa se nepopravljiva šteta ako društvo i država ne iskoriste znanje, mudrost i vještine koje je starija generacija akademika akumulirala tijekom svoje karijere. Velika većina starijih profesora može doprinijeti i sudjelovati u razvoju društva. U ovom članku prikazujemo rezultate istraživanja o akademskim i životnim aktivnostima članova Centra za umirovljene i zaslužne profesore Sveučilišta u Mariboru. Rezultati istraživanja pokazuju da je velika većina umirovljenih i zaslužnih profesora aktivna $\mathrm{u}$ akademskom životu i konstruktivno doprinosi razvoju i djelovanju Sveučilišta. 


\section{INTRODUCTION}

Population aging is one of the most pressing political issues in the 21st century. Life expectancy has increased in recent decades thanks to better living conditions, better medical care, new technologies in medicine and better health care in general. According to Eurostat, the European Union has a population of 446 million (the third most populous area in the world after China and India), it has 24 official languages and 27 Member States. In 2019 , more than a fifth $(20.3 \%)$ of the EU-27 population was at least 65 years old. The share of people aged 80 and over in the EU-27 is expected to increase 2.5 times between 2019 and 2100 (from $5.8 \%$ to $14.6 \%$ ) /1/, /2/. Europeans therefore live longer and, on average, stay in good health for longer. Life expectancy at birth has increased by approximately 10 years for both men and women over the past five decades. Life expectancy at birth for men, which was 78.2 years in 2018, is projected to increase to 86.1 years by 2070 . For women, it was 83.7 years and is estimated to increase to 90.3 years. Place of residence has a major impact on life expectancy. There are differences between women and men living in different parts of the EU. In the EU-27, life expectancy is 5.5 years higher for women at birth than for men, but it is not the same everywhere $/ \mathbf{2}$. Demographic change will affect not only healthcare but even more so the economy and the labor market.

Our present and the culture of modern society glorify youth and youthful appearance as an ideal to be worshiped throughout life. The marketing of beauty and youth is extremely lively, the social pressure to be in good shape without wrinkles and extra pounds is strong. We recognize the real stereotypes of aging in books and movies, and most of all in real life. In real life, the image of older people in our country is widespread, where the deterioration of physical and mental abilities progresses and their contribution to society decreases. They draw from society instead of contribute and they are unable to adapt to new technologies.
The last but not least, they spend huge funds on health care and long-term care $/ 3 /, / 4 /$.

However, throughout history this has not always been the case. In many indigenous cultures, the Council of Elders, elderly, and old members of society had a special honor and authority. The experience and knowledge of those who lived longer were highly valued especially during times of various conflicts, wars, famines or other life difficulties. Even today, the help of grandparents is a valuable, as they know how to advise, help and prevent various problematic situations and harms, care for sick family members and help in life in general $/ 4 /, / 5 /$. In many Asian modern cultures, older members of the family are still traditionally worshiped, and until recently, 3 to 4 generations lived together in one household. Thus, the knowledge that has accumulated over time is passed from generation to generation. Otherwise, the possibilities and options of living together differ in different parts of the world.

Around the world, the areas with the highest number of centenarians are marked as "Blue Zones" and include Sardinia in Italy, Nicoya in Costa Rica, Ikaria in Greece, Loma Linda in California, and Okinawa in Japan /6/, /7/. These places are home to 10 times more centenarians than other parts of the world. These people/centenarians are constantly physically active, live without much stress, in slower pace, they eat foods high in vegetables and fewer calories, sometimes they consume moderate amounts of wine, they are very close to family and have strong friendship bonds, and practice faith and prayer. Despite the fact that centenarians live in different parts of the world, their comon characteristics are the same - they are much respected in the family and their social environment, and they regularly contribute to the society with their experience and knowledge.

How long are we going to live? New research suggests that cell reprogramming may alter the process of cellular aging leading to a decline in 
mesenchymal stem / stromal cell (MSC) activity and function, but the underlying mechanisms are unclear. A protein known as GATA6 has been found to play a key role in this reverse process. These findings will help improve understanding of MSC aging and its importance in regenerative medicine (8). Therefore, predictions that our grandchildren and great-grandchildren will live significantly longer than the current generation, i.e. 150-200 years are not without basis.

The age of 60 or 65 , which is approximately equal to the retirement age in most developed countries, represents the onset of old age. Retirement is defined as the completion of a job or career, usually in late adulthood, due to the age or length of service required for retirement. It is the time of termination of employment with the simultaneous commencement of receiving a pension, which represents a milestone in an individual's life /8/. Retirement brings along various psychological, social, economic changes in the life of the retiree, so it cannot be perceived solely as an objective event, and coping with retirement strongly depends on personality traits, professional role, social networks and self-image.

\section{OBJECTIVE OF THE RESEARCH, POPULATION AND METHOD}

The aim of our research was to assess the academic and life activities of retired professors of the University of Maribor.

The sample on which the research was constructed was non-random and purposeful. The population in the study included professors emeriti and retired higher education teachers of the University of Maribor. The study involved 50 retired professors from the
University of Maribor, of which 34 men (68\%) and 16 women (32\%) aged 64 to 87 years. In order to ensure impartiality, only individuals who were able to complete the questionnaire independently were included in the study.

For the purposes of the research, we designed an anonymous questionnaire, consisting of closed and opened type of questions. The questionnaire covered three different areas. The first part of the questionnaire contained demographic data of respondents (gender, age, field of education and field of activity, marital status, etc.) and data on length of service and retirement. The second part contained data regarding the health status of the respondents. The third part of the questionnaire contained specific questions about the lifestyle of retired respondents, their hobbies, social contacts, and questions about their involvement in the scientific, research and academic environment.

The questionnaire was prepared with the 1.KA online application and it was distributed to the study participants directly through e-mail or indirectly through the Center of Professors Emeriti and Retired Higher Education Teachers of University of Maribor. Data were collected from January to March 2021.

The collected data were statistically processed using IBM SPSS 27.0 (IBM Corp. Armonk, NY).

\section{RESULTS}

The mean age of participants included in the study was $76.2 \pm 5.7$; for men it was $78.2 \pm 4.9$ years and for women $71.9 \pm 5.1$ years ranging from the youngest retired professor aged 64 to the oldest aged 87. 
Table 1: General data on participants of the study

\begin{tabular}{|c|c|c|}
\hline & $\mathrm{n}=50$ & $\%$ \\
\hline \multicolumn{3}{|l|}{ Gender } \\
\hline men & 34 & 68.0 \\
\hline women & 16 & 32.0 \\
\hline \multicolumn{3}{|l|}{ Maritial status } \\
\hline single (never married) & 1 & 2.0 \\
\hline married & 40 & 80.0 \\
\hline widowed & 2 & 4.0 \\
\hline divorced & 1 & 2.0 \\
\hline living together & 3 & 6.0 \\
\hline no answer & 3 & 6.0 \\
\hline \multicolumn{3}{|l|}{ Working life } \\
\hline 35 years & 5 & 10.0 \\
\hline 40 years & 19 & 38.0 \\
\hline 45 years & 13 & 26.0 \\
\hline 50 years & 8 & 16.0 \\
\hline no answer & 4 & 8.0 \\
\hline \multicolumn{3}{|l|}{ Place of living } \\
\hline own house & 32 & 64.0 \\
\hline own apartment & 13 & 26.0 \\
\hline tenant of the house & 0 & 0.0 \\
\hline tenant of the apartment & 1 & 2.0 \\
\hline no answer & 4 & 8.0 \\
\hline \multicolumn{3}{|l|}{ Pension } \\
\hline sufficient for the lifestyle & 44 & 88.0 \\
\hline not sufficient for the lifestyle & 2 & 4.0 \\
\hline no answer & 4 & 8.0 \\
\hline
\end{tabular}

Legend: $\mathrm{n}=$ number of answers, $\%=$ share

The study involved $3(6 \%)$ assistant professors, $6(12 \%)$ associate professors, $18(36 \%)$ full professors and 21 (42\%) emeriti professors. The largest part of participating retired professors had 40 years of service $(\mathrm{N}=19 ; 10 \%)$, fewer had 45 years of service $(\mathrm{N}=13 ; 26 \%)$, and the least part of the participants had 35 years of service $(\mathrm{N}=5 ; 10 \%)$. Eight $(16 \%)$ of retired professors who participated in the study had 50 years of service. Participants of the study were retired for an average of $10.1 \pm 5.4$ years (from 1.5 years to a maximum of 27 years in retirement).

The results showed that retired professors mostly lived in their own houses ( $\mathrm{N}=32 ; 64 \%)$ and their pension was sufficient for the lifestyle they enjoyed in retirement ( $\mathrm{N}=44 ; 88 \%)$. Majority of the retired professors were married ( $\mathrm{N}=40$ or $80 \%$ ) (Table 1 ). 
Table 2: Professional work of retired professors

\begin{tabular}{|c|c|c|}
\hline & $\mathrm{n}=50$ & $\%$ \\
\hline \multicolumn{3}{|l|}{ Faculty / field of education } \\
\hline Humanities & 4 & 8.0 \\
\hline Medicine & 13 & 26.0 \\
\hline Art & 0 & 0.0 \\
\hline Natural sciences & 7 & 14.0 \\
\hline Social sciences, law and economics & 14 & 28.0 \\
\hline Technical and environmental sciences & 14 & 28.0 \\
\hline World religions & 0 & 0.0 \\
\hline \multicolumn{3}{|l|}{ Field of working } \\
\hline Humanities & 4 & 8.0 \\
\hline Medicine & 13 & 26.0 \\
\hline Art & 0 & 0.0 \\
\hline Natural sciences & 4 & 8.0 \\
\hline Social sciences, law and economics & 14 & 28.0 \\
\hline Technical and environmental sciences & 18 & 36.0 \\
\hline World religions & 0 & 0.0 \\
\hline Area change and interdisciplinary work & 22 & 44.0 \\
\hline Attending scientific and professional meetings & 32 & 64.0 \\
\hline Atttending scientific or professional conferences & 15 & 30.0 \\
\hline Member of th committee for defending doctoral dissertations & 19 & 38.0 \\
\hline Reviewer of the research projects & 13 & 26.0 \\
\hline Reviewer of articles of domestic scientific or professional journals & 22 & 44.0 \\
\hline Reviewer of articles of international scientific or professional journals & 19 & 38.0 \\
\hline Writting recommendations to younger colleagues & 26 & 52.0 \\
\hline Writting consents for habilitations & 17 & 34.0 \\
\hline Member of habilitation commissions for election to academic titles & 14 & 28.0 \\
\hline Working as a researchers & 17 & 34.0 \\
\hline Leader of a research project & 3 & 6.0 \\
\hline Subject holder in Faculty & 15 & 30.0 \\
\hline Lecturing to the same extent as before retirement & 7 & 14.0 \\
\hline Lecturing to the lesser extent as before retirement & 13 & 26.0 \\
\hline Lecturing in foreign language & 12 & 24.0 \\
\hline Being invited lecturer at a foreign university & 7 & 14.0 \\
\hline
\end{tabular}

Legend: $n=$ number of answers, $\%=$ share

The field of education was not the same as the field of activity for all participants of the study. The results showed that $14(28 \%)$ of retired professors who participated in the study were educated in the field of technical and environmental sciences and the same number of them were educated in the field of social sciences, law and economics, while a slightly smaller percentage $(\mathrm{N}=13 ; 26 \%)$ of retired professors were from the medical field. The smallest share $(\mathrm{N}=4 ; 8 \%)$ of retired professors were educated in the field of humanities.

There were slightly more retired professors in the field of technical and environmental sciences than they were educated, namely 18 (36\%) of professors, indicating the transition between fields for some of the participants (Table 2). The results showed that retired professors were still quite active and more than half of them still attended scientific and 
professional meetings ( $\mathrm{N}=32 ; 64 \%)$, while 15 $(30 \%)$ of retired professors still attended conferences. $26(52 \%)$ of retired professors stated that they still write recommendations to younger colleagues and $7(14 \%)$ of them are still lecturing as invited lecturers at foreign universities while 7 (14\%) of them still gave lectures at foreign universities as invited lecturers.

Table 3: Health information of retired professors

\begin{tabular}{|c|c|c|}
\hline & $\mathrm{n}=50$ & $\%$ \\
\hline \multicolumn{3}{|l|}{ Diet } \\
\hline Normal, mixed & 45 & 90.0 \\
\hline Vegetarian & 0 & 0.0 \\
\hline Restricted & 2 & 4.0 \\
\hline No answer & 3 & 6.0 \\
\hline \multicolumn{3}{|l|}{ Dietary supplements } \\
\hline Probiotics & 8 & 16.0 \\
\hline Vitamins & 19 & 38.0 \\
\hline Antioxidants & 5 & 10.0 \\
\hline Chronic disease & 25 & 50.0 \\
\hline High blood pressure & 6 & 12.0 \\
\hline Kidney disease & 0 & 0.0 \\
\hline Cardiovascular disease & 5 & 10.0 \\
\hline Neurological disease & 0 & 0.0 \\
\hline Eye disease & 2 & 2.0 \\
\hline Diabetes & 4 & 8.0 \\
\hline Other & 13 & 26.0 \\
\hline \multicolumn{3}{|l|}{ Number of medications per day } \\
\hline One & 4 & 8.0 \\
\hline Two & 11 & 22.0 \\
\hline Three & 10 & 20.0 \\
\hline Four & 7 & 14.0 \\
\hline Five or more & 4 & 8.0 \\
\hline \multicolumn{3}{|l|}{ Sight } \\
\hline Normal & 8 & 16.0 \\
\hline Wearing eyeglasses & 32 & 64.0 \\
\hline Operated & 7 & 14.0 \\
\hline No answer & 3 & 6.0 \\
\hline \multicolumn{3}{|l|}{ Hearing } \\
\hline Normal & 28 & 56.0 \\
\hline Reduced & 10 & 20.0 \\
\hline Deaf & 0 & 0.0 \\
\hline Wearing hearing aid & 8 & 16.0 \\
\hline No answer & 4 & 8.0 \\
\hline \multicolumn{3}{|l|}{ Orthopedic mobility aids } \\
\hline Walking stick & 2 & 4.0 \\
\hline Walking crutches & 0 & 0.0 \\
\hline Electric wheelchair & 0 & 0.0 \\
\hline
\end{tabular}


The study also assessed the health status of retired professors (Table 3). Our results showed, that most of the participating retired professors enjoyed normal mixed diet $(\mathrm{N}=45$; $90 \%)$. The avarage body mass index of participants was $26.4 \pm 2.9 \mathrm{~kg} / \mathrm{m}^{2}$ (ranging from 20.4 to $\left.33.8 \mathrm{~kg} / \mathrm{m}^{2}\right)$. Retired professors also enjoyed dietary supplements; 8 (16\%) of them were taking probiotics; 19 (38\%) were taking vitamins and $5(10 \%)$ of them antioxidants.

Table 4: The social life of retired professors
Half $(\mathrm{N}=25 ; 50 \%)$ of the participants had a diagnosis of chronic disease, namely $6(12 \%)$ suffered from high blood pressure, 4 (8\%) had diabetes, and $13(26 \%)$ retired professors declared having other chronic diseases. Furthermore, 11 (22\%) of participants were taking two medications a day, two $(4 \%)$ retired professors were using walking sticks. 8 (16\%) retired professors stated that they have normal vision, while $32(64 \%)$ were wearing glasses. Normal hearing was reported by more than a half of retired professors $(\mathrm{N}=28 ; 56 \%)$.

\begin{tabular}{|l|l|l|}
\hline & $\mathrm{n}=50$ & $\%$ \\
\hline Do you always insist on your rights & & \\
\hline Do you feel that your rights have been violated due to age & 26 & 52.0 \\
\hline Do you feel discriminated because of your age & 6 & 12.0 \\
\hline Do you say what you think & 4 & 8.0 \\
\hline Hobbies & 40 & 80.0 \\
\hline painting & & \\
\hline literature & 0 & 0.0 \\
\hline sport & 7 & 14.0 \\
\hline politics & 9 & 18.0 \\
\hline music & 2 & 4.0 \\
\hline other & 4 & 8.0 \\
\hline no answer & 20 & 40.0 \\
\hline Do you devote more time to reflection and spirituality & 8 & 16.0 \\
\hline Activities during the day & 28 & 56.0 \\
\hline you get up in the morning the same as always & & \\
\hline you get up later in the morning & 29 & 58.0 \\
\hline no answer & 15 & 30.0 \\
\hline Do you still have a valid driver's license & 6 & 12.0 \\
\hline Do you still drive on longer distances & 41 & 82.0 \\
\hline Do you avoid driving long distances & 32 & 64.0 \\
\hline Do you take advantage of "senior" discounts in stores & 14 & 28.0 \\
\hline Do you attend cultural events & 21 & 42.0 \\
\hline Do you attend events at a university or college & 38 & 76.0 \\
\hline Do you travel to distant places & 37 & 74.0 \\
\hline on your own & & \\
\hline organized & 24 & 48.0 \\
\hline no answer & 12 & 24.0 \\
\hline wocial contacts & 14 & 28.0 \\
\hline with family members & & \\
\hline different interest circles & 42 & 84.0 \\
\hline friends & 34 & 68.0 \\
\hline & 39 & 78.0 \\
\hline & 1 & 2.0 \\
\hline
\end{tabular}




\begin{tabular}{|c|l|l|}
\hline on social networks & 1 & 2.0 \\
\hline What sport do you do? & & \\
\hline walks & 36 & 72.0 \\
\hline exercise & 11 & 22.0 \\
\hline hiking & 10 & 20.0 \\
\hline cycling & 11 & 22.0 \\
\hline swimming & 13 & 26.0 \\
\hline organized sports & 3 & 6.0 \\
\hline How many times a week do you do sports & & \\
\hline everyday & 21 & 42.0 \\
\hline several times a week & 11 & 22.0 \\
\hline once a week & 3 & 6.0 \\
\hline almost nothing / irregular & 15 & 30,0 \\
\hline
\end{tabular}

Legend: $n=$ number of answers, $\%=$ share

$26(52 \%)$ of retired professors stated that they insist on their rights. Only $6(12 \%)$ believed that their rights had been violated due to age, and 4 $(8 \%)$ of them felt that they are discriminated in some way due to their age. More than a half of retired professors kept their usual work rythm as during their active years and continued waking up in the morning as before retirement $(\mathrm{N}=29 ; 58 \%)$.

Our results showed that retired professors were still traveling long distances $(\mathrm{N}=32 ; 64 \%)$, attended cultural events $(\mathrm{N}=38 ; 76 \%)$, faculty and university events $(\mathrm{N}=37 ; 74 \%)$ and still traveled to distant destinations on their own ( $\mathrm{N}$ $=24 ; 48 \%)$ or organized $(\mathrm{N}=12 ; 24 \%)$.

Retired professors older than 65 years of age stated that they had more time for their hobbies and activities in retirement for which they did not have enough time before. More than a half of participants $(\mathrm{N}=28 ; 56 \%)$ devoted more time to reflection and spirituality in retirement.

They also state that they have more time for reading philosophical literature, for regular recreation and sports (cycling, sailing, etc.), for long walks in nature ( $\mathrm{N}=36 ; 72 \%)$, music and a healthy diet. Some are engaged in forensic expertise. Others devot more time for working in the garden, vineyard, and have more time for family ( $\mathrm{N}=42 ; 84 \%$ ) and friends ( $\mathrm{N}=39 ; 78 \%$ ).

\section{DISCUSSION}

Retired and distinguished professors most likely represent the privileged retirees. We had a secure and solidly paid work, received a good pension and most importantly most of us did our job with joy, in constant contact with young, bright students, whose questions needed to be answered according to the latest scientific knowledge and encourage their ideas. Professors who postpone retirement or are retired and participate in college are often seen as a financial burden for college and as an obstacle to the promotion of younger colleagues waiting to advance. Most institutions are not aware of the capital represented by senior professors. Some are scientists of international renown, some are top lecturers, some are excellent leaders of departments, divisions, faculties, some are excellent organizers who they know how to obtain projects, and also have a network of scientific connections at home and abroad. Nevertheless, many times they are simply dismissed upon retirement and instantly become a thing of the past.

Many retired and distinguished professors belong to the "baby boom" generation that has aged, fulfilled the conditions for retirement but they still more or less postpone the retirement. In their professional and academic paths, they have developed a lot of intellectual and social capital, have international scientific and friendly connections around the world with 
which they can help younger colleagues open paths to the world of science and support new, innovative projects. Therefore, it would be expected that these "veterans" are strategically involved in serving the faculty and the University. What an invaluable pity it is not to take advantage of such intellectual capital! The fact that we live longer and healthier than the generations before us is also reflected in the results of our research, which showed that the majority of the retired professors were in good health and still quite active with more than half of them still attending scientific and professional meetings and conferences. Some of the participants and even lectured at foreign universities as invited speakers.

We live in a time when much is required and expected from higher education and there is a lot of room for retired professors. Like other active researchers in Slovenia, they must evaluate their success and publications in accordance with Sicris requirements. This ensures fair treatment of all and high standards of excellence for everyone.

In November 2019, a group of enthusiasts, retired and distinguished professors of the University of Maribor established the Center of Professors Emeriti and Retired Higher Education Teachers of University of Maribor. They prepared the vision, mission, purpose and rules of operating, and organized 6 working groups: e-learning and e-education, Medicine, Culture and Art History, Demographic Change, Environmental Protection, Sustainable Development /9/.

It is a new model of development where long and hard-earned experience and knowledge of retired professors will be used in a new way of contributing to the development of the University and society.

\section{CONCLUSION}

Retirement causes changes in life, but this does not mean that creativity and energy dry up, they only need to be redirected and continue to have and achieve goals in life, because whoever has "what" to live for, carries almost every "how" /10/. Although age causes particular changes and those changes do change the meaning of life in certain respects, that does not mean that the meaning of life is gone if a person stays creative and uses the opportunities to redirect their own energy /11/.

The results of our research showed that the majority of retired professors are still academically active and associated with University of Maribor. As retirees, we can do what we want and change it according to our wishes. We identified the following main categories of activities in retirement.

1. Dedication to family, friends, enjoying nature, walking, gardening, reading fiction or philosophical works, listening to music, playing an instrument, traveling, etc.

2. Continuation of academic life as lecturers at home and abroad, as members of various commissions (habilitation, doctoral defense commissions, etc.), participation in scientific and professional meetings, conferences, as members of research groups, research project leaders, etc.

3. We use our knowledge and experience in a different way and in a different field, interdisciplinary. There are many opportunities for new roles and actions in which the knowledge acquired at the University comes in very handy.

Notes

/1/ Data from official website of the European Union. Available at: https//ec.europa.eu/eurostat/tgm/table.do?/table \&init $=1 \&$ language $=$ de \&pcode $=$ tps $00001 \&$ plugin $=1$. Accessed:April2018

/2/ COM(2020) 456 final: Čas za Evropo: obnova in priprava za naslednjo generacijo 17.6.2020 $\operatorname{COM}(2020) 241$ final Poročilo komisije evropskemu parlamentu, svetu, evropskemu ekonomsko - socialnemu odboru in odboru regij o vplivu demografskih sprememb.

Dodatne informacije so na voljo na Eurostatovi spletni strani "Statistics Explained" S statističnimi podatki o umrljivosti in pričakovani življenjski

dobi:

Coden: IORME7 
https://ec.europa.eu/eurostat/statistics-

explained/index.php?title=Mortality_and_life_e xpectancy_statistics

/3/ Aronson L. Elderhood. (2019), NewYork, NY: Bloomsbury

/4/ GreweW, Bjorklund D.F. (2009), The Nestor effect: Extending evolutionary developmental psychology

to

lifespanperspective.Developmental Review, 29.163-179.

/5/ Hall J.G. (2020), Continuing contribution of older academics, AmJ Med Genet.; 1:11

/6/ Buettner D. (2015), The Blue Zones Solution: Eating and Living Like the World's Healthiest People, by National Geographic

/7/ Levitin D. J. (2020), Successful aging: A neuroscientist explores the power and potential of our v letulives, NewYork, NY:Dutton
/8/ Hongli J,. Walczak B.E., Ming-Song Lee, Lemieux M.E., Li W.J (2021), GATA6 regulates aging of human mesenchymal stem/stromal cells, Steam cells, 39:62-77

19/ Glavič P. (2020), Poročilo o delu Centra za zaslužne in upokojene visokošolske učitelje Univerze v Mariboru v letu 2020

/10/ Frankl E.V. (1992), Kljub vsemu reči življenju da. Celje, Mohorjeva družba, str. 83-84.

/11/ Starc M, Doživljanje sreče. (2013), Ljubljana: Inštitut Antona Trstenjaka v: Staranje v Sloveniji,ur. Ramovš J., 199-221.151-165.

\section{ACKNOWLEDGEMENT}

The authors sincerely thank all participants in the research for their participation.

Thanks to Mr. Alojz Tapajner for statistical analysis of data. 